\title{
Muramic Acid Detection in Mammalian Tissues by Gas- Liquid Chromatography-Mass Spectrometry
}

\author{
ALVIN FOX,' JOHN H. SCHWAB, '* AND TEENA COCHRAN ${ }^{2}$ \\ Department of Bacteriology and Immunology, School of Medicine, University of North Carolina, Chapel \\ Hill, North Carolina 27514, ${ }^{1}$ and National Institute of Environmental Health Sciences, Research Triangle \\ Park, North Carolina $27509^{2}$
}

\begin{abstract}
Muramic acid is a component of the peptidoglycan moiety of cell walls of all bacteria and blue-green algae and is not found elsewhere in nature. A gas-liquid chromatography-mass spectrometry assay for muramic acid in tissue is described. The application of the method to the detection of muramic acid in tissues of rats with streptococcal cell wall-induced polyarthritis is demonstrated. Because the method has the potential to measure total bacterial biomass in tissue, it should prove to be an important assay in elucidating the etiological role of bacterial debris in chronic inflammatory diseases in humans.
\end{abstract}

Chronic, remittant, erosive arthritis is induced in rats by a single intraperitoneal (i.p.) injection of an aqueous suspension of group A streptococcal cell wall fragments (4). The inflammation is associated with localization and persistence of cell wall antigen in the synovium and periarticular tissues, as demonstrated qualitatively by immunofluorescent techniques (4). The clinical, radiological, and histological similarities between the experimental model and human disease $(3,4)$ have led to the hypothesis that chronic inflammatory arthritides in humans, such as rheumatoid arthritis or Reiter's syndrome, can result from the localization and persistence of toxic, immunogenic, bacterial cell wall fragments $(4,19,20)$. To test this hypothesis it is essential to be able to detect bacterial cell walls in tissue, even though these cell walls may be derived from unknown species.

Muramic acid is a component of the peptidoglycan moiety of cell walls of all bacteria and blue-green algae and is unique to these microorganisms (18). For this reason it provides a naturally occurring internal label for bacterial cell walls, and thus the detection of muramic acid in tissue provides evidence for the presence of bacterial cell wall debris. Although numerous techniques have been published for the analysis of muramic acid $(2,6,8,9,11-13,16)$, the only method able to identify this compound at trace levels in a complex matrix such as tissue is gas-liquid chromatography-mass spectrometry (GLC-MS).

In this report we describe a new GLC-MS assay for muramic acid and illustrate the application of the method to the detection of muramic acid in tissues of rats with streptococcal cell wall-induced polyarthritis. Because measure- ment of muramic acid reflects the bacterial biomass in tissue, it should prove useful in the study of bacterial infections, as well as in elucidating the possible etiological role of bacterial debris in human arthritides.

\section{MATERIALS AND METHODS}

Preparation of bacterial cell wall fragments. The preparation of bacterial cell wall fragments has been described in detail (4). In brief, group A type 3 strain D58 cells were cultured in Todd-Hewitt broth (BBL, Cockeysville, Md.) in a Virtis fermentor (Virtis, Gardiner, N.Y.) and collected at early stationary phase by continuous-flow centrifugation (Ivan Sorvall, Inc., Newton, Conn.). The washed cells were disrupted in a Braun MSK cell homogenizer (Bronwill Scientific Inc., Rochester, N.Y.), and the cell walls were collected by centrifugation at $10,000 \times g$. The cell walls were washed three times with $\mathrm{pH} 7.2$ phosphate-buffered saline (PBS) and treated with ribonuclease $(0.025 \mathrm{mg} /$ $\mathrm{mg}$ of cell wall) at $37^{\circ} \mathrm{C}$ for $4 \mathrm{~h}$. They were washed once with PBS, treated with trypsin $(0.025 \mathrm{mg} / \mathrm{mg}$ of cell wall) at $37^{\circ} \mathrm{C}$ for $4 \mathrm{~h}$, washed once again with PBS, and then treated with papain $(0.020 \mathrm{mg} / \mathrm{mg}$ of cell wall) in $0.1 \mathrm{M}$ phosphate buffer ( $\mathrm{pH} 7.0$ ) containing $0.001 \mathrm{M}$ cysteine and $0.001 \mathrm{M}$ ethylenediaminetetraacetic acid (EDTA), at $37^{\circ} \mathrm{C}$ for $4 \mathrm{~h}$. They were washed three times with PBS and then three times in water and extracted three times with chloroform-methanol (2:1). After this extraction they were washed once in water, dialyzed against water for $24 \mathrm{~h}$, and lyophilized. To prepare cell wall fragments, the isolated cell walls were suspended at $20 \mathrm{mg} / \mathrm{ml}$ in PBS, ultrasonicated for $70 \mathrm{~min}$ in a Branson sonifier (model S125, Heat Systems Ultrasonics, Inc., Plainview, N.Y.), and then filtered through a series of sterile membrane filters (Millipore Corp., Bedford, Mass.) 3.0, 1.2, and $0.45 \mu \mathrm{m}$ in size. In addition to removing any bacterial contamination, the filtration also established the maximum particle size of cell wall fragments.

Induction of arthritis and collection of tissue 
specimens. Female Sprague-Dawley rats, each weighing approximately $100 \mathrm{~g}$, were given a single i.p. injection of group A streptococcal cell wall fragments suspended in PBS. The dose of cell wall injected contained $60 \mu \mathrm{g}$ of rhamnose per $\mathrm{g}$ of body weight. This amount is equivalent to approximately $20 \mathrm{mg}$ of cell wall per rat. Experimental animals and parallel controls injected with PBS were sacrificed at 3,6 , and 8 days after injection. After sacrifice the right fore leg from each animal was amputated, the skin was removed, and the carpus, metacarpus, and surrounding subcutaneous tissues were excised and frozen immediately at $-20^{\circ} \mathrm{C}$. Samples of liver and spleen were also stored at $-20^{\circ} \mathrm{C}$ until analysis.

Sample preparation for GLC-MS. Tissues were weighed and homogenized in $10 \mathrm{ml}$ of water in an Omnimixer (Sorvall). The homogenate was dialyzed against 6 liters of water for $16 \mathrm{~h}$ at $4^{\circ} \mathrm{C}$. The water was changed at $8 \mathrm{~h}$. A few drops of chloroform were added to the water to inhibit bacterial growth. The dialyzed samples were lyophilized and reweighed. A $30-\mathrm{mg}$ amount of dried sample in $1.0 \mathrm{ml}$ of $2 \mathrm{~N}$ sulfuric acid was placed in a reaction tube with an adjustable Teflon plunger (Pierce, Rockford, Ill.). The tubes were evacuated and flushed with nitrogen. The sample was then heated at $100^{\circ} \mathrm{C}$ in a heating module (Pierce) for $3 \mathrm{~h}$ and then cooled in an ice bath. A 10- $\mu$ g portion of muramic acid in $1 \mathrm{ml}$ of $2 \mathrm{~N}$ sulfuric acid was subjected to the same treatment through the entire procedure. A 5-ml amount of $20 \%$ di- $N$-octylmethylamine in chloroform was added to the sample. The sample was shaken, and, after $20 \mathrm{~min}$, the aqueous phase was removed and centrifuged at $1,000 \mathrm{rpm}$ for $10 \mathrm{~min}$. The muramic acid in the aqueous phase of the tissue samples was partially purified by thin-layer chromatography (TLC). Exactly $0.4 \mathrm{ml}$ of the aqueous phase was streaked on a 1-mm-thick preparative silica gel TLC plate with a preabsorptive area (Pierce). The plate was dried and chromatographed in a butanol-ethanolwater system (50:32:18). The $\boldsymbol{R}_{f}$ value of muramic acid on TLC is 0.5 , but the exact position of muramic acid was confirmed on each analysis by chromatographing a muramic acid standard and identifying it with ninhydrin spray reagent. After chromatography the plates were dried again, and an area $\pm 0.8 \mathrm{~cm}$ from the $R_{f}$ of muramic acid was loosened with a razor blade and removed by suction into a $10-\mathrm{ml}$ glass pipette plugged with glass wool. A 12-ml amount of chloroform was passed through the packed pipette to remove lipids released by hydrolysis, and this eluent was discarded. Muramic acid was eluted from the pipette with $12 \mathrm{ml}$ of methanol-water (7:3) under nitrogen pressure. A 5$\mu \mathrm{g}$ portion of glucosamine as an internal standard was added to the samples, and the samples were evaporated under nitrogen in a $55^{\circ} \mathrm{C}$ water bath ( $\mathrm{N}$-Evap, Organomation, Northborough, Mass.). They were then reacted with $5 \mathrm{mg}$ of sodium borohydride overnight at $4^{\circ} \mathrm{C}$ to destroy the anomeric center. Destruction of the anomeric center eliminates occurrence of multiple peaks upon gas chromatography. A 3-ml amount of acetic acid-methanol $(1: 200)$ was added to the sample and evaporated under nitrogen. This process was repeated five times. This step converts borohydride into trimethylborate, which is removed by evaporation. Borate, if present, inhibits the subsequent acetylation reaction. The samples were lyophilized for $3 \mathrm{~h}, 300 \mu \mathrm{l}$ of acetic anhydride was added, and the samples were heated for 13 to $16 \mathrm{~h}$ at $100^{\circ} \mathrm{C}$ in reaction vials with screw caps and Teflon-silicone disks (Pierce) in a heating module. This step converts alditols into the volatile alditol acetates (17). The samples were then evaporated to dryness under nitrogen. One milliliter of water and $1 \mathrm{ml}$ of chloroform were added to the derivatized sample, the emulsion was centrifuged, and the chloroform phase was removed and evaporated to dryness. This step removes polar compounds such as salts and amino acids. The derivatized sample was dissolved in $20 \mu \mathrm{l}$ of chloroform, and $2 \mu \mathrm{l}$ was analyzed on a $3920 \mathrm{~B}$ gas chromatograph equipped with a flame ionization detector and M2 calculating integrator (The Perkin Elmer Corp., Norwalk, Conn.). Chromatography was done on a glass column (6 feet by $2 \mathrm{~mm}$ ) packed with 3\% SP2340 on 100/120 mesh Supelcoport (Supelco, Bellefonte, $\mathrm{Pa}$.) with a temperature program having an initial temperature of $200^{\circ} \mathrm{C}$ increased at a rate of $4^{\circ} \mathrm{C}$ per min to a final temperature of $240^{\circ} \mathrm{C}$ The helium carrier gas flow was $40 \mathrm{ml} / \mathrm{min}$. The detector and injector were held at $250^{\circ} \mathrm{C}$. The concentration of muramic acid per gram (wet weight) of tissue was calculated as follows: $C=M \times G_{1} \times X / G$ $\times M_{1} \times W$, where $C=$ micrograms of muramic acid per gram of wet tissue; $M=$ area of muramic acid peak in tissue chromatogram; $G=$ area of glucosamine peak in tissue chromatogram; $M_{1}=$ area of muramic acid peak in standard chromatogram; $G_{1}=$ area of glucosamine peak in standard chromatogram; $X=$ micrograms of muramic acid in standard solution; and $W$ = weight of wet tissue analyzed.

Mass spectra were obtained on a Micromass 7070F (VG Micromass, Winford, England) mass spectrometer interfaced with a Sigma 3 gas chromatograph (Perkin Elmer). The mass spectrometer was equipped with an 8-channel multiple ion detection unit and a VG 203F Data System equipped with selective ion recording software package. To obtain quantitative trace analysis by GLC-MS, selective ion monitoring for peaks $m / e 168,210$, and 228 was performed.

Reagents for GLC. Reagents and sources were as follows: chloroform, methanol, and butanol, all glass distilled, from Burdick and Jackson, Muskegon, Mich.; ethanol, glass distilled, from MCB, Cincinnati, Ohio; acetic acid, ultrex grade, from Baker, Phillipsburg, N.J.; di- $N$-octylmethylamine, ICN, Plainview, N.Y.; acetic anhydride from Applied Science Laboratories, State College, Pa.; sodium borohydride and sulfuric acid from Fisher Scientific Co., Pittsburgh, Pa.; muramic acid from P-L Biochemicals, Milwaukee, Wisc.; D-glucosamine hydrochloride from Calbiochem, La Jolla, Calif.; and water, which was double distilled.

\section{RESULTS}

The alditol acetate method (17) was chosen for derivatization of muramic acid since it produces a single peak on gas chromatography, in contrast to other methods such as silylation (2). This makes interpretation of the chromatograms simpler and also increases sensitivity. The alditol acetate of muramic acid (pentaacetyl muramicitol) has a molecular weight of 463 . In 


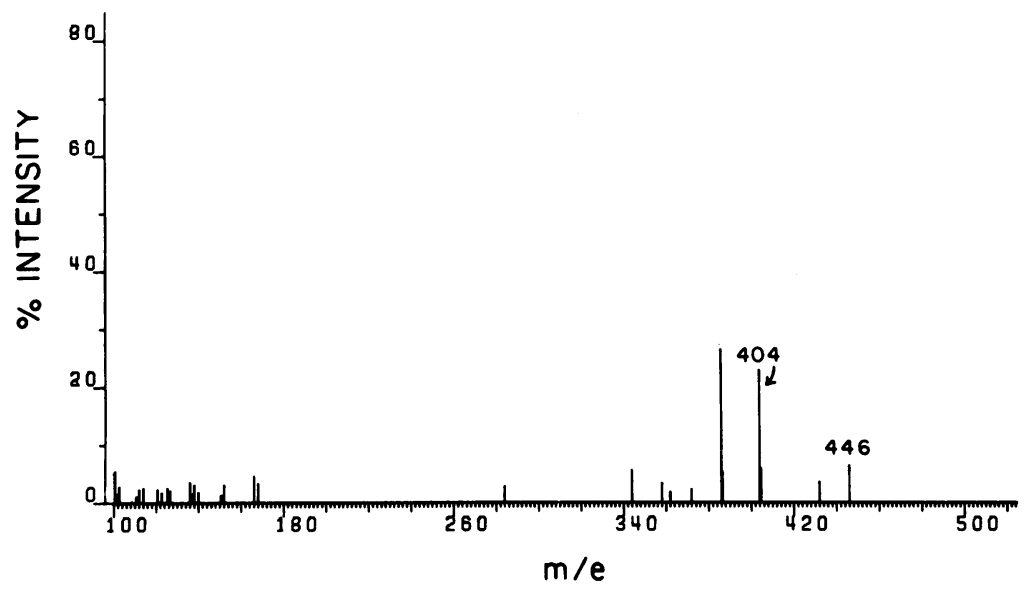

FIG. 1. Chemical ionization (methane) mass spectrum of pentaacetyl muramicitol.

preliminary experiments the chemical ionization mass spectrum of derivatives of muramic acid was obtained by using methane as the ionizing gas (Fig. 1). This analysis was done to look for the presence of a molecular ion (M) with an $\mathrm{m} /$ $e$ of 463 , which would confirm the chemical nature of the derivative of muramic acid. A molecular ion of $m / e 463$ was not seen, but mass ions at 446 and 404 were detected. The ion at 446 would be produced by the derivative gaining a hydrogen ion and losing water $\left(\mathbf{M H}-\mathrm{H}_{2} \mathrm{O}\right)$, whereas the ion at 404 would be obtained by loss of an acetyl group $\left(\mathrm{M}-\mathrm{CH}_{3} \mathrm{CO}_{2} \cdot\right)^{+}$. Alditol acetates are extremely unstable even under mild ionization conditions, such as chemical ionization, and commonly decompose, losing water or acetyl groups (10). Thus, the data support the conclusion that pentaacetyl muramicitol was produced.

Samples of spleen and liver from arthritic rats injected up to 8 days previously with group A streptococcal cell wall fragments and samples from normal controls were analyzed by the alditol acetate method described. A peak having a retention time of $818 \mathrm{~s}$, equal to that of muramic acid derivatized in an identical fashion, was resolved in the gas chromatogram of tissues from arthritic rats; however, this peak was not present in samples of normal rat tissues (Fig. 2). Although these data alone are strong evidence that this peak is derived from muramic acid, it is possible that inflamed tissue contains a compound having a retention time equal to that of muramic acid and that this compound is not present in normal tissue. Accordingly, the peak resolved in the gas chromatogram of tissue from arthritic rats was analyzed by GLC-MS. The electron ionization mass spectrum of this material was identical to that of the alditol acetate of
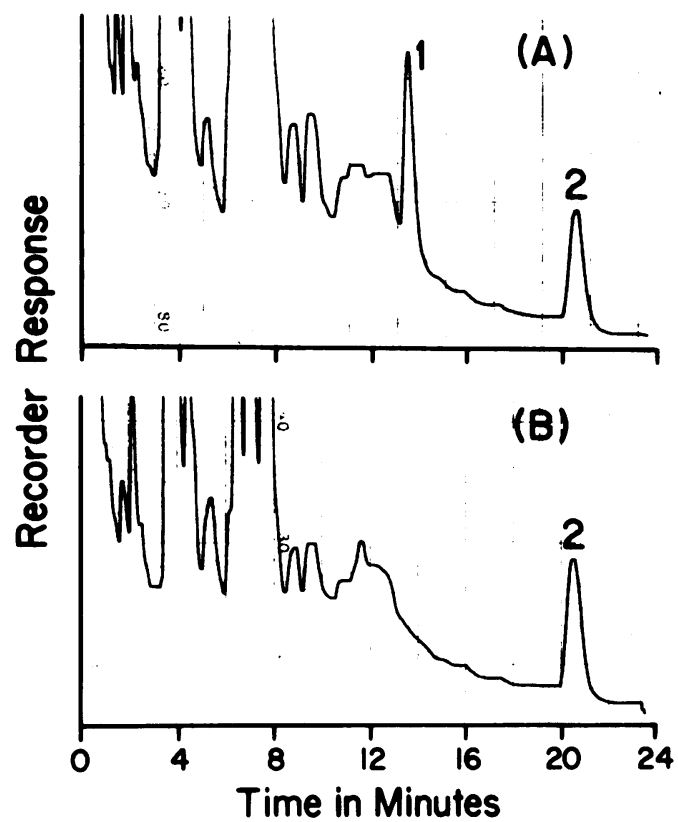

Fig. 2. Gas chromatogram of alditol acetate de. rivatives of $(A)$ extract of spleen from animal injected i.p. 6 days previously with cell wall fragments and $(B)$ extract of normal spleen. Peak 1 corresponds to muramic acid; peak 2 corresponds to the internal standard glucosamine. Other peaks are derived from tissue components.

muramic acid, which confirms the identity of the material as muramic acid (Fig. 3).

Having definitively confirmed the presence of muramic acid in the spleens and livers of rats injected i.p. with streptococcal cell walls, we next looked for the presence of muramic acid in arthritic joints where it would only be present in trace amounts. The electron ionization mass 


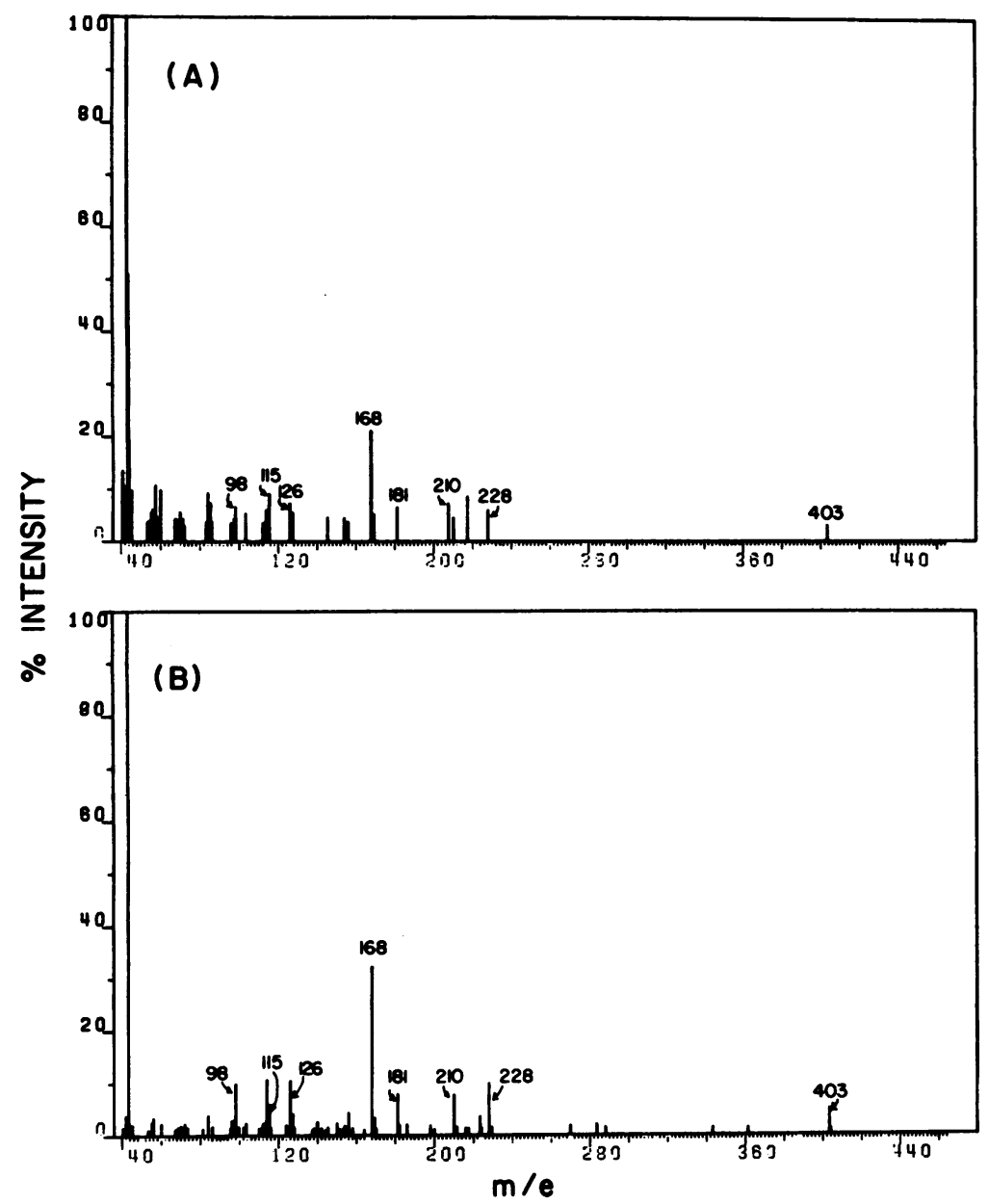

Fig. 3. (A) Electron ionization mass spectrum of the muramic acid peak in a gas chromatogram of an extract of spleen from an animal injected 8 days previously with cell wall fragments. (B) Pentaacetyl muramicitol reference standard.

spectrum of muramic acid contains prominent mass ions at $m / e 168,210$, and 228 . Therefore, instead of obtaining a complete mass spectrum, selective ion monitoring was done to detect the ions 168,210 , and 228 in peaks resolved from the gas chromatogram. This results in a 1,000 -fold increase in sensitivity, because the instrument is focusing on only these three ions rather than on the entire spectrum (22). By this method, muramic acid was detected in joints from arthritic animals, but not normal controls (Tables 1 and 2).

Many questions arising in this rat arthritis system, such as differences in arthropathogenicity of differing particle sizes of group A cell wall fragments (A. Fox, R. Brown, and J. H. Schwab, IX Eur. Cong. Rheum. p. 203, 1979) and differences in susceptibility of various strains of rat to development of arthritis (1), are
TABLE 1. Quantitation of muramic acid in spleens of rats by GLC

\begin{tabular}{cc}
\hline Animal no. & $\begin{array}{c}\text { Muramic acid }(\mu \mathrm{g}) / \mathrm{g} \text { (wet wt) } \\
\text { of tissue }\end{array}$ \\
\hline 1 & 68.5 \\
2 & 40.7 \\
& 54.0 \\
& 58.6 \\
4 & 56.1 \\
5 & 51.1 \\
& 201.1 \\
6 & 186.5 \\
& 49.8 \\
& 75.3 \\
\hline
\end{tabular}

${ }^{a}$ Rats were injected i.p. 6 days previously with 20 mg of group A streptococcal cell wall fragments. Tissues from six control rats, injected with PBS, had no detectable muramic acid. 
TABLE 2. Quantitation of muramic acid in joints of rats by GLC-MS employing selective ion monitoring

\begin{tabular}{ccccc}
\hline \multirow{2}{*}{$\begin{array}{c}\text { Animal } \\
\text { no. }^{a}\end{array}$} & $\begin{array}{c}\text { Days post- } \\
\text { injection }\end{array}$ & \multicolumn{3}{c}{$\begin{array}{c}\text { Muramic acid }(\mu \mathrm{g}) / \mathrm{g} \text { (wet wt) of } \\
\text { tissue }^{b}\end{array}$} \\
\cline { 3 - 5 } & & $m / e$ 168 & $m / e$ 210 & $m / e$ 228 \\
\hline 1 & 3 & 0.9 & 0.8 & 0.8 \\
2 & 3 & 0.4 & 0.4 & 0.4 \\
3 & 8 & 0.4 & 0.3 & 0.4 \\
4 & 8 & 0.2 & 0.2 & 0.2 \\
5 & 8 & 1.0 & 0.9 & 0.9 \\
6 & 8 & 0.7 & 0.6 & 0.7 \\
\hline
\end{tabular}

${ }^{a}$ Rats were injected i.p. with $20 \mathrm{mg}$ of group A streptococcal cell wall fragments.

${ }^{b}$ Calculated from the area of the respective ions in a derivatized extract of joint tissue, compared to the corresponding ion areas in a muramic acid standard. Background values for each ion, obtained with extracts from normal rat joints, have been subtracted.

probably related to persistence and localization of cell wall debris. Therefore, it is necessary not only to be able to detect muramic acid but to measure its concentration in tissue. The quantitation of muramic acid in spleens of rats killed 6 days after i.p. injection of cell wall fragments is shown in Table 1. Tissues from control rats, injected with PBS, had no detectable muramic acid. The muramic acid in extracts of joints of rats injected with cell wall fragments is shown in Table 2. The data in Table 2 were obtained with selective ion monitoring and were similar whether the data were based on ions 168,210 , or 228. This provides evidence of the specificity of the method for muramic acid.

The coefficient of variation of the entire assay was $19 \%$. This was measured with six replicates of the same normal liver sample containing added muramic acid and glucosamine as an internal standard. The recovery of muramic acid in tissue was $83.4 \%$. This was determined with six replicate tissue samples containing added muramic acid, compared with six replicate samples of muramic acid alone. Both sets of samples contained glucosamine added as an internal standard.

\section{DISCUSSION}

After local or systemic injection, bacterial cell wall structures can persist in tissue and cause chronic inflammation in experimental animals $(4,14,15,20)$. On the basis of these earlier studies we have proposed that human diseases, such as rheumatoid arthritis, may result from the localization and persistence of bacterial cell wall debris $(4,19,20)$. Such debris could be derived from a variety of bacterial species. This hypothesis can be tested by analyzing tissue samples chemically for components unique to bacterial cell walls. Muramic acid is such a component, being present in cell walls of all bacteria but found nowhere else in nature. A new GLCMS assay for detection and quantitation of muramic acid in tissues is presented here, and the method is applied to detect muramic acid in tissues of rats previously injected with group A streptococcal cell wall fragments.

Other methods for the detection of bacterial cell wall in tissue such as external labeling with ${ }^{125}$ I (5), fluorescein (7), or rhodamine (21) or internal labeling with ${ }^{14} \mathrm{C}$ (R. S. Jones and J. R. Ward, Arth. Rheum. 5:650-651, 1962), present several problems. These include uncertainty of the precise component which is labeled, possible alteration of biological properties by the conjugation, and uncertainty that the label remains associated with cell wall structures in vivo. $\mathrm{Ob}$ viously, these methods are of no use in the study of human patients. Detection of cell wall antigens by immunofluorescence or radioimmunoassay can be applied to human tissue specimens, but the specificity of the antigen being sought must be known before testing. In addition, host antibody could block the antigenic site (23) or the host may modify immunodeterminants on cell wall antigens. A chemical assay of muramic acid does not suffer from these constraints. The obvious advantage of the detection of this natural internal label is that the presence of cell wall debris from any bacterial species can be detected and quantitated in human as well as animal tissues.

The GLC-MS technique has the potential sensitivity of $10^{-15} \mathrm{~mol}$. The limitations are imposed by the background material from tissue components. We are presently employing TLC to remove a great deal of this background. However, TLC is time consuming, taking about $6 \mathrm{~h}$, and the subsequent elution of muramic acid from the silica gel plates is tedious. Furthermore, the precision of quantitation is limited by the selection of an appropriate internal standard. Ideally this standard should have an $\boldsymbol{R}_{f}$ identical to that of muramic acid on TLC and be derivatized to a volatile form by the alditol acetate method, but it should be well resolved from muramic acid by GLC-MS. Stable isotopic isomers $\left(\left[{ }^{13} \mathrm{C}\right]\right.$ muramic acid) or steric isomers (lactyl galactosamine or lactyl mannosamine) of natural muramic acid would be ideal but we have not yet been able to obtain them. The lack of a suitable internal standard has necessitated adding the glucosamine standard subsequent to elution of the samples from the silica gel. This reduces precision of quantitation. Glucosamine is used as an internal standard since glucosamine de- 
rived from tissue is removed on TLC (only material of $R_{f}=0.5$ is eluted and glucosamine remains at the origin), and muramic acid and glucosamine are well resolved by gas chromatography. Due to the problems mentioned we are currently developing an alternative to TLC and synthesis of a suitable internal standard.

The preliminary work presented here on the detection of bacterial cell walls in rat tissues shows that the assay has the potential for detection of this material in human tissue. This approach can thus contribute to the study of human arthritides by confirming that bacterial cell debris is an etiological factor. Furthermore, the demonstration that it is possible to detect one bacterial component in mammalian tissue encourages the development of techniques for the detection of other components characterizing subsets of bacteria. For example, diaminopimelic acid is found mainly in gram-negative and acidfast bacteria, 2-keto-deoxyoctonic acid is found in gram-negative bacteria, and mycolic acid is found in mycobacteria, nocardia, and corynebacteria. Such chemical analyses are potentially useful in investigation of the pathogenesis of bacterial infections.

\section{ACKNOWLEDGMENTS}

The excellent assistance of Roger Brown and Sonia Anderle is gratefully acknowledged.

This work was supported by Public Health Service research grant AM25703 from the National Institutes of Health.

\section{LTERATURE CITED}

1. Anderle, S. K., J. J. Greenblatt, W. J. Cromartie, R. Clark, and J. H. Schwab. 1979. Modulation of the susceptibility of inbred and outbred rats to arthritis induced by cell walls of group A streptococci. Infect. Immun. 25:484-490.

2. Casagrande, D. J., and K. Park. 1977. Simple gas chromatographic technique for the analysis of muramic acid. J. Chrom. 135:208-211.

3. Clark, R. L., J. T. Cuttino, S. K. Anderle, W. J. Cromartie, and J. H. Schwab. 1979. Radiologic analysis of arthritis in rats after systemic injection of streptococcal cell walls. Arthritis Rheum. 22:25-35.

4. Cromartie, W. J., J. G. Craddock, J. H. Schwab, S. K. Anderle, and C-H. Yang. 1977. Arthritis in rats after systemic injection of streptococcal cells or cell walls. J. Exp. Med. 146: 1585-1602.

5. Doble, A., A. Fox, L. E. Glynn, and D. Kingston. 1975 The non-passage of mycobacteria from Freund's complete adjuvant granuloma deposits to arthritic joints. Br. J. Exp. Pathol. 56:537-543.
6. Fazio, S. D., W. R. Mayberry, and D. C. White. 1979 Muramic acid assay in sediments. Appl. Environ. Microbiol. 38:349-350.

7. Ginsburg, I., and R. Trost. 1971. Localization of group A streptococci and particles of titanium dioxide in arthritic lesions in the rabbit. J. Infect. Dis. 123:292-296.

8. Hadzija, O. 1974. A simple method for the quantitative determination of muramic acid. Anal. Biochem. 60:512517.

9. King, J. D., and D. C. White. 1977. Muramic acid as a measure of microbial biomass in estuarine and marine samples. Appl. Env. Microbiol. 33:777-783.

10. Lönngren, J., and S. Svennson. 1974. Mass spectrometry in structural analysis of natural carbohydrates. Adv. Carbohyd. Chem. Biochem. 29:41-106.

11. Millar, W. N., and L. E. Casida. 1970. Evidence for muramic acid in soil. Can. J. Microbiol. 16:299-304.

12. Moss, C. W., F. J. Diaz, and M. A. Lambert. 1971 Determination of diaminopimelic acid, ornithine and muramic acid by gas chromatography. Anal. Biochem. 44:458-461.

13. Moriarty, D. J. W. A method for estimating the biomass of bacteria in aquatic sediments and its application to trophic studies. Oecologia (Berlin) 20:219-229.

14. Ohanian, S. H., and J. H. Schwab. 1967. Persistence of group A streptococcal cell walls related to chronic inflammation of rabbit dermal connective tissue. J. Exp. Med. 125:1137-1148.

15. Ohanian, S. H., J. H. Schwab, and W. J. Cromartie. 1969. Relation of rheumatic-like cardiac lesions of the mouse to localization of group A streptococcal cell walls. J. Exp. Med. 29:37-49.

16. Rosan, B. 1972. Determination of murainic acid in automated amino acid analysis. Anal. Biochem. 48:624-628.

17. Sawardeker, J. S., J. H. Sloneker, and A. Jeanes. 1965. Quantitative determination of monosaccharides as their alditol acetates by gas liquid chromatography. Anal. Chem. 37:1602-1604.

18. Schleifer, K. H., and O. Kandler. 1972. Peptidoglycan types of bacterial cell walls and their taxonomic implications. Bacteriol. Rev. 36:407-477.

19. Schwab, J. H. 1970. Significance of bacterial components in the pathogenesis of connective tissue disease, p. 226232. Proc. IV Int. Congr. Pharmacol.

20. Schwab, J. H., W. J. Cromartie, S. H. Ohanian, and J. G. Craddock. 1967. Association of experimental chronic arthritis with the persistence of group A streptococcal cell walls in the articular tissue. J. Bacteriol 94:1728-1735.

21. Vernon-Roberts, B., S. P. Liyanage, and H. L. F. Currey. 1976. Adjuvant arthritis in the rat. Distribution of fluorescent material after footpad injection of rhodamine-labelled tubercle bacilli. Ann. Rheum. Dis. 35:389-397.

22. Watson, J. T. 1976. Introduction to mass spectrometry: biomedical, environmental, and forensic applications. Raven Press, New York.

23. Wheat, L. J., R. B. Kohler, and A. White. 1978. Solidphase radioimmunoassay for detection of staphylococcal antigen in serum of rabbits with endocarditis due to Staphylococcus aureus. J. Infect. Dis. 138:174-178. 